\title{
Interactive comment on "Impact of Spaceborne Carbon Monoxide Observations from the S-5P platform on Tropospheric Composition Analyses and Forecasts” by R. Abida et al.
}

\section{R. Abida et al.}

attj@@aero.obs-mip.fr

Received and published: 30 June 2016

Dear editor,

Please find attached our response to referee 1.

Please also note the supplement to this comment:

http://www.atmos-chem-phys-discuss.net/acp-2015-924/acp-2015-924-AC1supplement.pdf

Interactive comment on Atmos. Chem. Phys. Discuss., doi:10.5194/acp-2015-924, 2016. 